NBER WORKING PAPER SERIES

\title{
O.M.W. SPRAGUE (THE MAN WHO "WROTE THE BOOK" ON FINANCIAL CRISES) MEETS THE GREAT DEPRESSION
}

\author{
Hugh Rockoff \\ Working Paper 29416 \\ http://www.nber.org/papers/w29416 \\ NATIONAL BUREAU OF ECONOMIC RESEARCH \\ 1050 Massachusetts Avenue \\ Cambridge, MA 02138 \\ October 2021
}

This paper was prepared for the conference on International Lending of Last Resort in Historical and Theoretical Perspective held at the University of Oldenburg September 16-17, 2021 organized by Professor Hans-Michael Trautwein and sponsored by the Deutsche Bundesbank. I thank Nga Nguyen for helpful research assistance. I thank Michael Bordo, Robert Greenfield, Karl Hardach, David M. Levy, Perry Mehrling, Carolyn Moehling, Mary Tone Rodgers, Richard Sylla, and Eugene White for their advice and comments on a previous draft; and the participants in the discussion of the paper in Oldenburg for many helpful suggestions. None of these outstanding scholars is responsible for the remaining errors. The views expressed herein are those of the author and do not necessarily reflect the views of the National Bureau of Economic Research.

NBER working papers are circulated for discussion and comment purposes. They have not been peer-reviewed or been subject to the review by the NBER Board of Directors that accompanies official NBER publications.

(C) 2021 by Hugh Rockoff. All rights reserved. Short sections of text, not to exceed two paragraphs, may be quoted without explicit permission provided that full credit, including () notice, is given to the source. 
O.M.W. Sprague (the Man Who "Wrote the Book" on Financial Crises) meets the Great Depression Hugh Rockoff

NBER Working Paper No. 29416

October 2021

JEL No. B2,N12,N2

\begin{abstract}
$\underline{\text { ABSTRACT }}$
When the Great Depression struck the United States, Oliver M.W. Sprague was America's foremost expert on financial crises. His History of Crises under the National Banking System is a frequently cited classic. Had he diagnosed a banking panic and called for an aggressive response by the Federal Reserve, it might have made a difference; but he did not. Sprague's misdiagnosis had, I argue, two causes. First, the crisis lacked the symptoms of a panic, such as high short-term interest rates in the New York money market, which Sprague had identified from his studies of previous crises. Second, Sprague's macro-economic ideas led him to conclude that an expansionary monetary policy would be of little help once a depression was underway. Sprague's main concern was that abandoning the gold standard would intensify the crisis, a concern that led him to resign his position as advisor to the U.S. Treasury to protest Roosevelt's gold policy.
\end{abstract}

Hugh Rockoff

Department of Economics

Rutgers University

75 Hamilton Street

New Brunswick, NJ 08901-1248

and NBER

rockoff@econ.rutgers.edu 


\section{Oliver Mitchell Wentworth Sprague}

When the Great Depression struck, O.M.W. Sprague was America's foremost expert on financial crises. ${ }^{1}$ Sprague was, literally, the man who "wrote the book" on financial crises: His History of Crises under the National Banking System (1910), written for the National Monetary Commission, is a frequently cited classic.

His eminence was widely recognized at the time. Educated at Harvard, he was the first professor appointed to an endowed chair at Harvard's Graduate School of Business, where he taught banking and finance. From 1930 to 1933, he served as special adviser to the Bank of England, and briefly during 1933 (more on this below) as special adviser to the U.S. Treasury. At other times, he served as consultant to the Reichsbank, the Bank of France, and the League of Nations. In 1937 he was elected president of the American Economic Association.

Had Sprague diagnosed a banking panic and called for an aggressive lender-of-last resort intervention by the Federal Reserve, it might have made a difference. However, Sprague never diagnosed a crisis in the

\footnotetext{
${ }^{1}$ Sprague was born in 1873. He was an undergraduate and graduate student at Harvard, where he did his Ph.D. in Political Science (Sprague 1897). He died in 1953. Cole, Masson, and Williams (1954) is a detailed obituary.
} 
1930s requiring the Federal Reserve to act as lender of last resort, and he was skeptical about the potential benefits of an expansionary monetary policy to ameliorate the Great Depression once it was underway. Here, I try to explain why Sprague misdiagnosed the banking problems of the 1930 s and why he was skeptical about the value of an expansionary monetary policy. Moreover, while Sprague was an important influence, I believe that his views were typical of many other experts during the Great Depression. Sprague's misdiagnosis was not the result of a lack of knowledge about the history of financial panics. Indeed, no one in the United States knew more about that history. However, as I will show in detail below, Sprague had identified certain symptoms of financial panics, such as high short-term interest rates in the New York money market, that were absent in the early 1930s. In other words, the banking troubles of the early 1930 s did not look to Sprague like a typical banking crisis; they looked like a very different ailment.

Sprague, although a force at the time, has not received much attention from historians of economic thought. For the most part, they have focused on economists whose ideas still influence current discussions, such as Keynes, Fisher, Hayek, Schumpeter, and so on. 
Among them, Irving Fisher demands extra attention. Fisher, perhaps more than any other American economist, was an influential public figure at the time who remains a person of interest for economists and historians of economic thought. Fisher, unlike Sprague, called for an expansionary monetary policy to combat the contraction of the early 1930s. Fisher's reputation, however, had been seriously damaged because two weeks before the 1929 stock market crash Fisher, who had established a reputation as an expert on the stock market, had declared that stock prices had reached "what looks like a permanently high plateau" (New York Times, October 16, 1929, 8). ${ }^{2}$ Sprague's reputation, on the other hand, had been enhanced by his call in May 1929 for the Federal Reserve to raise its discount rate to discourage stock market speculation. "If things go along until stock prices are too high," he warned, "a serious collapse will follow" (New York Times, May 2, 1929, 9; Wall Street Journal, May 11, $1929,5)$. Sprague, to sum up, had a well-earned reputation as an expert on banking and finance, and his views probably carried more weight than Fisher's, or those of any other expert.

Friedman and Schwartz $(1963,410-11)$ noted Sprague's failure to call for the Federal Reserve to act as Lender of Last Resort during the banking

\footnotetext{
${ }^{2}$ Fisher's reputation has not been enhanced by his tendency to take up causes including prohibition, vegetarianism, stamped money, simplified spelling, and most unfortunately, eugenics.
} 
panics of 1930-31, and lumped Sprague in with other academics who had been closely associated with the founding of the Federal Reserve.

"Most surprising, some of those whose work had done most to lay the groundwork for the Federal Reserve Act or who had been most intimately associated with its formulation - for example, O.M.W. Sprague, E.E. Kemmerer, and H. Parker Willis - were least perceptive, perhaps because they had so strong an intellectual commitment to the view that the Federal Reserve System had once and for all solved problems of liquidity."

While this explanation contains a measure of truth, here I will argue that at least in Sprague case, the two factors I noted above (the lack of typical symptoms of a panic in the early 1930s and lack of confidence in the effectiveness of an expansionary monetary policy) were more important.

Because it helps to clarify Sprague's approach, I will also compare and contrast Sprague's History of Crises under the National Banking System (1910), with the book that often is called the bible of central banking: Bagehot's Lombard Street (1873). Sprague did not cite Bagehot in the History of Crises, although he did cite Bagehot approvingly in several journal articles, including one published shortly before the History was published in which he refers to Lombard Street as "indispensable" for an understanding of the British banking system (1909b, 376). Rather, I compare Sprague and Bagehot because they were working on similar scholarly projects. Both were examining past cases of financial crises - 
Sprague the American crises after the Civil War, Bagehot the British crises after the Napoleonic Wars - to determine the causes, identifying symptoms, and best treatments for financial crises. Their studies, therefore, illuminate each other. ${ }^{3}$

We can think Bagehot and Sprague as money doctors trying to identify the symptoms of an economic malady and the best course of treatment - indeed Bagehot (1923 [1873], 51) wrote that a financial panic is a "species of neuralgia".

\section{The Symptoms of a Crisis}

In the History of Crises Sprague considers the five crises that occurred subsequent to the passage of the National Banking Act in 1863: the Crisis of 1873, the Panic of May 1884, the Financial Stringency of 1890, the Crisis of 1893, and the Crisis of 1907. These are Sprague's descriptions, and they make it clear that he regarded 1884 and 1890 as less serious events.

Each case study covers a similar set of issues. Four are what I term the symptoms of a crisis: (1) the nature of the failures that triggered the crisis, (2) the situation in New York, the nation's financial center, (3) the balance

\footnotetext{
${ }^{3}$ Sprague was aware, of course, that the financial world had changed a good deal from Bagehot's day, and so Bagehot's recommendations needed updating. This was one of the points made by Withers (1909), another expert on British financial markets that Sprague cited approvingly.
} 
sheets of the banks, in particular the reserve positions of the leading banks in New York, and (4) interest rates, especially short-term rates in New York. In addition, Sprague discussed a number of other aspects of the crises, such as their effects on domestic and foreign trade, but here I will focus on the symptoms.

\subsection{The Failures that Trigger Crises.}

In Lombard Street, Bagehot (1924 [1873], 118) concluded that there was a variety of shocks that might trigger a panic:

"a bad harvest, an apprehension of foreign invasion, the sudden failure of a great firm which everybody trusted, and many other similar events, have all caused a sudden demand for cash."

However, because he was considering panics after the Napoleonic Wars, the shocks he examined were mostly failures of "a great firm which everybody trusted."

Particularly influential in Bagehot's thinking, I believe, was the Panic of 1866 the last panic before the publication of Lombard Street. This panic was triggered by the failure of Overend, Gurney \& Co. Before the crisis, according to Bagehot (1924 [1873], 17), Overend, Gurney stood "next to the Bank of England in the City of London" and was "the most trusted private firm in England" (1924 [1873], 175), a perfect example of "a great 
firm which everybody trusted." ${ }^{4}$ Similarly, Sprague's case studies all include discussions of the important failures that triggered the panic. Often, I should note, the trigger was not a single failure, but a cluster of failures.

The failure of Jay Cooke and Company, a prominent investment bank, on September 18, 1873 that Sprague discussed in his chapter on the Crisis of 1873 fits the mold of "a great firm that everybody trusted." Cooke was well known to the public as well as in financial circles because Salmon Chase, Lincoln's Secretary of the Treasury, had chosen him to market the Union's debt during the Civil War, a task that he was thought to have carried out with great success. Cooke's failure, moreover, was part of a cluster that included the failure of the New York Warehouse and Security Company on September 8, and the failure of Kenyon, Cox \& Co., a New York brokerage on September 13 (Sprague 1910, 35-36).

The Panic of May 1884 was triggered by the failure on May 8, of the investment house of Grant and Ward. Grant was Ulysses S. Grant, the savior of the union, and twice president of the United States, and then still one of the most admired living Americans. There were also troubles at several national banks. Suspension of payments by the Metropolitan National Bank of New York on May 14 spurred the New York Clearing

\footnotetext{
${ }^{4} \mathrm{I}$ explore the shocks that triggered American financial panics in Rockoff (2018 and 2021).
} 
House - an association of the largest banks in New York created for clearing checks, although by then taking on a broader role - to action. It issued "clearing house loan certificates," a form of near money, to relieve pressures on reserves.

What Sprague referred to as the "Financial Stringency of 1890" was sparked by a cluster of failures in November 1890. Chief among them was the failure of Decker, Howell \& Co., a brokerage that the New York Times (Nov 12, 1890, 1) referred to as "one of the foremost firms established in Wall Street." Sprague also noted the impact of the near failure of Baring Brothers in London, a renowned investment bank.

The Crisis of 1893 did not involve any large New York financial houses. However, Sprague cited the failure of the Pennsylvania and Reading Railroad in February and the failure of the National Cordage Company in May as triggers for the meltdown in the stock market (Sprague 1910, 163-64). While he noted that there were bank failures in the South and West, he did not identify the failure of a major bank in those regions that could have sparked a national crisis.

The Crisis of 1907, the last before Sprague wrote the History of Crises, was triggered by the failure of the Knickerbocker Trust in New York, on October 22, 1907. Several commercial banks had been in trouble before 
the Knickerbocker and they had been helped by the Clearing House. Rumors suggested that the Knickerbocker was involved in the same speculations that had undermined those banks, but the Clearing House refused to help the Knickerbocker, and this led to runs with which the Knickerbocker could not cope. Sprague discussed this failure at length. He concluded that if the Knickerbocker and the other trust companies had been helped, the crisis of 1907 might have been averted (Sprague 1910, 246-56).

This interpretation of the Crisis, I should add, is purely Sprague's. I believe, however, that the subsequent literature has filled in the details in his account and brought to light aspects of the Crisis that he did not address rather than overturn his principal conclusions. Moen and Tallman (1992), for example, showed that runs were focused on the trust companies to an extent that previous researchers had not recognized. And Rodgers and Payne (2014) showed that, perhaps surprisingly, actions taken by the Bank of France were helpful in stabilizing the stock market.

To sum up, if Sprague was looking to his own case studies, he would have expected a financial crisis to be triggered by the failure of a wellknown and well-regarded financial institution, probably based in New York, although he had noted failures of industrial firms and of Jay Cooke in 
Philadelphia. However, as far as I have been able to learn, Sprague never identified a failure that resembled these earlier triggering failures during the early 1930s.

True, later writers have identified failures that they thought had triggered a crisis in the early 1930s. Friedman and Schwartz (1963, 309312), for example, identified the failure of the Bank of United States on December 11, 1930 as a major turning point. In a long footnote in $A$ Monetary History they $(1963,309)$ described the efforts to save the bank. The plan was to merge the Bank of United States with several other banks in New York and to inject $\$ 30$ million provided by the Clearing House banks into the new institution. It would not have been the sort of intervention described by Bagehot in Lombard Street, but it would have been similar to the rescue operation organized by the Bank of England in the Barings crisis. $^{5}$

In A Monetary History Friedman and Schwartz (1963, 310n. 9) provide only hints as to why the plan to rescue the Bank of United States fell apart. In some of his popular writings and in his influential 1980 TV series, "Free to Choose," Friedman went further in identifying the failure of the Bank of United States as the trigger for the crisis and in explaining the

${ }^{5}$ See White (2016) for a description of how the Barings Crisis was handled by the Bank of England. 
reasons why the bank was not rescued. He began Episode 3, "Anatomy of a Crisis," with scenes in which he is looking at the building that housed the Bank of United States. ${ }^{6}$ (A picture of the run on the bank is at the end of the paper.) Friedman tells the viewer that this was where the crucial event occurred that turned a recession into the Great Depression. ${ }^{7}$

Although the Bank of United States had a large deposit base and its home office was located close to Wall Street, it was not a Wall Street Bank. It served a mainly Jewish clientele on the Lower East Side of New York. Anti-Semitism, Friedman suggested, was one of the reasons why the bank was not rescued. Friedman and Schwartz $(1963,355)$ claimed, moreover, that the Bank had paid out well when it was liquidated and that the Bank was therefore a good candidate for a rescue. These contentions have been challenged (Lucia 1985, O'Brien1992, and Trescott 1992) and defended (Friedman and Schwartz 1986). However, for our purposes, this debate is a side issue. Whether the authorities at the Federal Reserve and the New York Clearing House thought that the effects of a closing of the Bank of United States would be limited because only local businesses and

\footnotetext{
${ }^{6}$ The episode can be watched on YouTube, as of 10-15-2021.

${ }^{7}$ The book that accompanied the television series, Friedman and Friedman (1980), also gives a starring role to the failure of the Bank of United States.
} 
depositors would be affected, or because only local Jewish businesses and Jewish depositors would be affected, it is clear that the failure of the Bank of United States was considered a community bank, albeit a very large community bank. It did not fit the profile of "a great firm which everybody trusted" that Bagehot, and to judge from his discussions in the History of Crises, Sprague, would have considered a potential trigger for a financial panic.

Elmus Wicker $(1980 ; 1996,32-36)$ drew attention to the failure of Caldwell and Company, a large southern investment bank. Within the South, it probably did qualify as "a great firm that everybody trusted." According to John McFerrin $(1969,119)$, the historian of Caldwell and Company, by then "it had so increased its size and built up such prestige in financial circles that it was referred to as the "Morgan of the South." Again, as the case of the Bank of United States, it did not conform fully to the profile of a bank whose failure Sprague might have thought would trigger a panic - it was not a Philadelphia or New York bank.

In any event, Sprague, as far as I have been able to determine, did not comment publicly on the failure of the Bank of United States, the failure of Caldwell and Company, or the failure of any other large financial institution that might have been of sufficient importance to trigger a panic. 
Although the Bank of United States was located in New York City and had a large deposit base, it was not a Wall Street Bank and did not currently have an outstanding reputation (corruption was widely rumored) although it once did so (Temin 1976, 90-93). Caldwell and Company, although it had an outstanding reputation at the time it failed, was a Southern bank not a Wall Street bank. It was the Morgan of the South, not Morgan.

\subsection{The Reserves of the Biggest New York Banks}

A central conclusion of the History of Crises was that the biggest New York banks, six or seven national banks, held the ultimate cash reserve of the banking system, just as in Bagehot's Britain the Bank of England held the ultimate reserve. Sometimes the U.S. banking system was described as a pyramid. Country banks would deposit money in outlying reserve cities, for example in St. Louis or Atlanta, and then those banks would deposit money in New York to use as reserves. Thus, a small amount of cash in a few New York banks was the tip of a large pyramid. It was important, Sprague concluded, that in a crisis the big New York banks act in concert as lender of last resort. In this respect, Sprague conclusion was much like Bagehot's. Bagehot argued that the Bank of England held the ultimate reserve, and 
although it was a private bank, it had a social responsibility to maintain the stability of the financial system.

All of the crises that Sprague described in his History of Crises were centered, ultimately, in New York. For Sprague events in New York such as the issue of Clearing House loan certificates or the suspension of cash payments were important markers of the crises under the National Banking Act.

True, country bank failures could be an important part of a crisis. ${ }^{8}$ In Sprague's discussion of the crisis 1893 - the crisis that, in my view, was most similar to the crisis of 1929-33 - Sprague notes several waves of bank failures in rural areas. However, he does not describe these waves in detail, and does not identify any of the institutions involved.

He divides the 1893 crisis into three stages. The first stage was primarily a slump on the stock market, analogous to the stock market crash of 1929. The second stage was marked by waves of bank failures in the South and West (Sprague 1910, 167-68, 175), again analogous to events in 1930-33. In the third stage, the problem returned to New York. Some of the important New York banks had seen their reserves fall to dangerously low levels, and so the New York banks led the way in what became a

\footnotetext{
${ }^{8}$ Recent research (Richardson 2007. Michener and Richardson 2013) has shown that drains of cash from
} New York to the interior played an important role in producing the banking crisis of the 1930 s. 
national suspension of specie payments, an action that Sprague thought had disastrous consequences (Sprague 1910, 200).

Perhaps if Sprague had recalled and focused on the first two stages of the 1893 crisis when he was thinking about the financial problems in the early years of the Depression, he would have called for the Federal Reserve to take actions to end the crisis. However, in the 1930s, the final stage of the 1893 crisis, a nationwide suspension of payments inaugurated by the New York banks, was avoided. Indeed, even as a wave of bank holidays in which local authorities and state governors closed banking systems spread across the country in the interregnum between the election of Roosevelt in 1932 and his taking office in early 1933, the New York banks remained open. Thus, if one focusses on New York, the final stage of the banking crisis of 1929-33 does not look like the final stage of the 1893 crisis. $^{9}$

Sprague's focus on New York is the analog of Bagehot's focus on London. The full title of Bagehot's classic was Lombard Street: A Description of the Money Market. A similar book about the United States would have been Wall Street: A Description of the Money Market. Wall

\footnotetext{
${ }^{9}$ Richardson and Troost (2009) and Carlson, Mitchener, and Richardson (2011) have shown that the Atlanta Federal Reserve Bank did recognize the panic in its district and acted aggressively and successfully as lender of last resort to mitigate the crisis.
} 
Street was the location of the stock market crash of 1929, but it was not the location of the banking panics of the early 1930s. There were problems in New York, but in the main, the panics of the early 1930s were interior panics.

\subsection{Balance sheets}

In the History of Crises Sprague analyzed the balance sheets of the U.S. commercial banks (there was no central bank), particularly the largest National Banks of New York in considerable detail. His main concern was whether there was enough cash in these New York banks - what Sprague referred to as the "ultimate reserve" of the banking system - to satisfy demands from the interior.

In describing the crisis of 1893 , for example, Sprague presents four tables showing the balance sheets of the banks (Sprague 1910; $163,167,173,190)$. He considers two issues. Were there adequate reserves in New York to prevent the crisis (yes) and did banks reinforce the contraction by reducing loans (yes). A key sign of the crisis for Sprague was the loss of cash reserves in New York. Between May 4 and July 12, spanning what Sprague calls the second phase of the Crisis, the New York banks lost \$21.4 million, about 20 percent of their reserves. Banks in other 
parts of the country also lost reserves, but nothing in quantity or percentage terms like the New York banks (Sprague 1910, 173).

Here again there is a close parallel with Bagehot (1924 [1873], 17071) who cites figures on the bullion reserve of the Bank of England to show that in the panic years the Bank allowed its reserve to fall to dangerously low levels. Levels that Bagehot thought alarmed the public and brought the financial system close to panic.

Table 1 shows annual data on all commercial banks and all banks in New York State from 1928 to 1934, the sort of data that Sprague examined in his case studies. For all banks, the all-important currency and coin column, does show some evidence of the banking crisis, but the amount available does not fall below the 1929 level until 1932. The amount actually increases between 1929 and 1930 and between 1930 and 1931. For New York banks, there is a small decline in 1931. Nevertheless, the level in1931 is higher than in 1928 or 1929. Other items show more cause for alarm. For all banks, total loans decline steadily from 1929 to 1934. And for New York banks there is a steady fall in total loans after the rebound between 1929 and 1930. Still, for one focused on holdings of cash and currency in New York, a panic would not be an obvious call before 1932. 
After the founding of the Federal Reserve, moreover, the Federal Reserve held the ultimate reserve, not the big banks in New York. Table 2 shows selected items from the balance sheet of the Federal Reserve from 1928 to 1934 . Again, several items attest to a crisis. Total U.S. securities held by the Federal Reserve increases in each year, reflecting the attempt by the Federal Reserve to overcome the slump by pumping money into financial markets. By 1934, the amount of U.S. Securities held by the Federal Reserve is more than 10 times what it was in 1928.

However, the all-important gold reserve presents a benign picture. The Federal Reserve's stock of gold rose in each year from 1928 to 1934. Someone looking to the Federal Reserve's bullion reserves to tell them whether what was happening to the financial system - as Sprague might have done as he changed his focus from the leading private banks in New York to the Federal Reserve - might well have missed the crisis.

\subsection{High Short-term Interest Rates}

Short-term interest rates were discussed in each of the case studies in the History of Crises. Call loans were a particular concern to Sprague. These were loans made, usually, by the big New York banks to securities brokers. They were secured by stock and callable on demand. In turn, these loans 
provided funds for the brokers to lend to their clients. To each New York bank separately, Sprague $(1910,301-302)$ noted, call loans appeared to be extremely liquid. The bank's money was parked around the corner, so to speak, in the stock market and could be recalled at any moment. However, Sprague argued, call loans were not liquid for the New York banks as a whole during a financial crisis, as evidenced by the extraordinary rates that were sometimes charged for them. It was dangerous, Sprague emphasized, for the holders of the nation's ultimate reserve to depend on this spurious source of liquidity.

Figures 1-5 show some key short-term rates in each of the five crises that Sprague discusses in History of Crises while Figure 6 shows those rates in 1930-31. In each case, I have plotted the rates in a 12-month window surrounding the key failure that appears to have sparked the crisis. Figures 1-5 provide brief visual summaries of a substantial part of the History of Crises. There are many tables in the History of Crises, but no charts. And while writing this account, I had a strong feeling that had Sprague had access to Excel and the St. Louis Fred website, he would have made good use of them.

Figure 1 shows short-term rates during the Crisis of 1873. Sprague, like most financial historians, as I noted above, identifies the failure of Jay 
Cooke and Company of Philadelphia as the spark that ignited the panic. The sharp spike in the Call Money Rate when Jay Cooke failed - it reached an annual rate of 40 percent in August 1873 - suggests that the call money rate is an excellent indicator of trouble in financial markets.

Figure 2 is similar. It shows rates during the Panic of May 1884. In this case, it was the failure of Grant and Ward, a broker/investment bank that was the trigger for the panic. Once again, the call money rate proves to be a good indicator of a financial crisis. It peaks at an annual rate of about $15 \%$ in the month when Grant and Ward failed.

Figure 3 shows short-term rates in the Financial Stringency of 1890. Here we see a spike of interest rates in August that Sprague attributed to a loss of gold reserves by the New York banks produced by American purchases of European securities. The rates then subside. However, another spike follows in November produced by a wave of bank failures in the Midwest and the near failure of Barings in London, a world famous investment bank.

Figure 4 shows the short-term rates during the Crisis of 1893. This figure, like Figure 3, also has two spikes. The first Sprague associated with the failure of the Pennsylvania and Reading Railroad. The second corresponds to a wave of bank failures in the Middle West that included 
several major banks such as the Chemical National Bank of Chicago, the Missouri National Bank of Kansas City, and the Wisconsin Marine and Fire Insurance Company (Mitchell's Bank) of Milwaukee.

Figure 5 shows the short-term rates during the Crisis of 1907 . Once again, there is a sharp spike in the call money rate when the key event occurs: when the Knickerbocker Trust closes its doors.

To sum up, a money doctor would be likely to conclude from an examination of Figures 1-5 that short-term rates - and in particular, the call money rate - were sensitive indicators of financial distress. Plotting them would provide a money doctor with a fever chart of a crisis.

When reviewing the crisis of 1914 - a crisis sparked by the outbreak of World War I in Europe - in a paper written after The History of Crises Sprague $(1915,520)$ noted that there had been no advance in interest rates. Sprague cited this in support of his thesis that the Crisis of 1914 had been met effectively through the issue of emergency Aldrich-Vreeland currency. Clearly, he was treating interest rates as an indicator of a panic.

With all this in mind, consider Figure 6, which shows short-term rates in the early 1930s. This chart is obviously very different from the previous charts. There had been increases in short rates between 1928 and 1929, because of the stock market boom and crash. However, short rates then 
fell to very low levels in 1930 and 1931 . While there was a slight increase in the call money rate from $2.00 \%$ in November 1930 to $2.23 \%$ in December, short rates in general simply continued their slide.

Short-term interest rates, to sum up, did not signal a major crisis during the key years at the start of the Great Depression as they had in earlier crises. Partly this was because the stock market crash and the banking crisis occurred close together in earlier crises, while in the 1930s they were separated, making the call money rate a less reliable sign of a financial crisis. Asking Sprague to confirm a diagnosis of panic in 1930-31 when the interest rates that he normally looked at to register the level of distress in financial markets were declining, is like asking a physician to confirm a diagnosis of pneumonia when the patient is not running a fever.

\section{Other Potential Symptoms}

Of course, Sprague might have focused on other variables in his case studies that might in turn have produced a better diagnosis of what was happening in the early 1930s. One obvious candidate is bank suspensions. Figure 7 shows bank suspensions - this includes both temporary and permanent suspensions of deposit redemptions and other activities - from 1890 to 1934 . The Great Depression clearly dominates the picture. There is 
also a noticeable spike in the crisis of 1893. However, the spike in 1908 following the crisis of 1907, the last crisis before the Great Depression is easily missed.

The rate of bank suspensions was considerably higher, moreover, in the prosperous 1920s than in 1907 or 1908. From this fact alone, one could conclude that number of bank suspensions was not a good symptom for diagnosing a financial panic. Sprague and Burgess (1929), moreover, examined the high number of bank failures in the 1920s in rural areas. They blamed these failures on depressed farm prices and overbanking. On the latter point, they $(1929,695)$ drew the following conclusion from their data on banks per capita.

"No community can possibly provide adequate resources, competent officers, and experienced directors for one bank to every 759 of its inhabitants as in North Dakota, or to 1,400 as in lowa. And the situation in these states was not exceptional; on the contrary, an excessive number of banks have been established throughout those sections of the country that are mainly devoted to agriculture."

Clearly, bank failures in these regions were to be expected if agricultural prices were falling, and although there would be costs imposed on agricultural communities, such failures would improve the functioning of the system by winnowing out small, inefficient banks. It is understandable, therefore, that Sprague would not view the surge of bank failures in 1930 in 
the same areas where bank failures were frequent in the 1920 s as a signal of the onset of a national banking panic.

Another set of potential symptoms was identified by Friedman and Schwartz who focused on the stock of money and its proximate determinants: the stock of high-powered money, the deposit-currency ratio and the deposit-reserve ratio.

Space does not permit a full recounting of the Friedman-Schwartz story. However, a sense of how looking at these variables would lead to a diagnosis of a banking crisis in the early 1930 s is conveyed by Figure 8 , which shows the deposit-currency and deposit-reserve ratios during 19291933. A fall in the deposit-currency ratio signals a panic because it means that depositors are withdrawing cash, and a fall in the deposit-reserve ratio signals a panic because it suggests that banks are reducing lending in order to build up their reserves. Friedman and Schwartz established that these variables declined during banking panics much in the same way that Sprague had established the importance of short-term rates, by examining financial crises in the United States after the Civil War. However, Figure 8 shows that these variables also identify a crisis in the early 1930s. They fall, and the fall begins with the failure of the Bank of United States. Friedman and Schwartz, of course, had the advantage that they were 
writing after they knew what had happened in the Great Depression.

Sprague's history of financial crises might have been very different if it was written after WW2.

To sum up, my conjecture is that Sprague failed to diagnose a financial crisis in early 1930 s because the symptoms he was looking for $-\mathrm{a}$ panic causing havoc in the New York money market, failures of wellregarded financial houses, a drain of gold from the holder of the ultimate reserve, and high short-term interest rates - were absent. True, he might have made a different diagnosis if he had looked at other variables, such as the Friedman and Schwartz variables, but these were not the variables that he had been taught to look for by his case studies of earlier panics.

\section{Sprague on Monetary Policy}

Sprague did not recognize the need for lender of last resort interventions, but what about using monetary policy to stimulate the economy as it contracted? While Sprague was not completely negative about the usefulness of monetary policy, he was extremely doubtful that monetary expansion could do much to help.

We have several excellent sources for Sprague's views on monetary policy. First, in the academic year 1929-1930 Sprague taught a course on 
bank management at the Harvard Graduate School of Business. Thanks to one of his students, we have a reliable transcript of his lectures: It was double-checked by a colleague of Sprague. Although nominally about bank management, Sprague's course ranged widely over current economic institutions and policies. The lectures reveal Sprague's remarkably wide and detailed knowledge of financial markets and his knowledge of current developments.

For most of the academic year, Sprague said little about monetary policy. Finally, in May of 1930 he addressed Federal Reserve policy. ${ }^{10}$ First, he made the point that to get the economy growing again the costs of doing business had to be reduced to make business profitable again. Interest, however, was only one component of costs, and not the largest. Therefore, it followed that lowering interest rates would not have a major impact on restoring economic activity. Sprague, however, was not entirely negative about lower interest rates at that time. The student reported Sprague's thoughts this way.

"If one takes a somewhat doubtful view of what may be accomplished by a great deal of credit, the case for lowering rates at a time like the present does not vanish, but the grounds for it become more negative than before. You will not be certain that a large volume of credit will increase business activity, but you can be sure that volume of credit

\footnotetext{
${ }^{10}$ Sprague's course ended before the "First Banking Panic" which began, according to Friedman and Schwartz, in October 1930, so it is not surprising that Sprague did not address possible Federal Reserve responses directed at bank failures.
} 
and low rates will remove an impediment to business revival." (Sprague 1930, May 5).

From 1930 to 1933, Sprague served as special advisor to the Bank of England. During that stint, he wrote a revealing paper, "Major and Minor Trade Fluctuations," read to the Royal Statistical Society in June 1931. It is clear from that paper that Sprague did not see the U.S. banking crisis as playing even a small role in the slump. His paper makes no mention of bank failures, let alone a banking crisis. Indeed, the central theme of Sprague's paper is a criticism of the view put forward by what he terms the "Monetary School" that central bank actions could help end the slump.

Sprague concedes that easy money policies helped restore the economy after recessions in 1923 and $1927 .{ }^{11}$ However, this recession, Sprague argued, was different. A number of sectoral imbalances existed, for example between agricultural and industrial prices that needed correction. Sprague $(1931,546)$ concluded that

"According to this view [Sprague's view] banking and other financial agencies cannot bring about a recovery from a major depression." ${ }^{2}$

\footnotetext{
${ }^{11}$ Sprague and Burgess (1929) make the same point.

12 Sprague expressed similar views in a May 1931 speech in London, which was widely reported in the press (Meltzer 2003, 277).
} 
Sprague's idea that the Depression reflected "structural imbalances" may strike the modern economist as idiosyncratic. In fact, however, it was a common and influential view at the time, and underlay early New Deal policies (Barber 1996).

In November and December 1933, Sprague published ten articles in the New York Times outlining his views about what should be done to restore the economy to health. These articles were later collected as Recovery and Common Sense (1934) $\cdot{ }^{13}$ Here Sprague expanded vigorously on his view that recovery could not be brought about through an expansionary monetary policy.

In one of these articles, Sprague acknowledged (New York Times, Dec 8, 1933; p. 22) that low bank lending was a problem and that deposit insurance would help restore confidence. However, he argued that everyone was to blame for the crisis, not just bankers: "Farmers who bid up the price of land and incurred heavy burdens of mortgages debts," "industrialists who over expanded capacity," and, yes, the Federal Reserve. But not its failure to increase the stock of money. "Heavy responsibility," wrote Sprague, "rests upon those conducting the Federal Reserve System for failure to effect needed restraint during the two years preceding the

${ }^{13}$ The book does not appear to differ in any significant way from the articles that appeared in the Times. 
collapse in 1929." Sprague did see a reason to blame the Federal Reserve for its lack of action in 1929-1933, because, I suggest, he saw no major mistakes during those years. It was too late for monetary policy to do much good.

Sprague's presidential address to the American Economic Association (1938) reiterated the main themes of this analysis. There was little that monetary policy could do. Interest rates were already low, and pushing them lower would not help. Inflation would not help. The main force for recovery had to come from the private sector. The best possibility was the development of large-scale businesses organized for providing low cost housing.

\section{Sprague on the Gold Standard}

Sprague remained at the Bank of England until May 1933. He then rushed back to the United States. On May 20 he met with Treasury Secretary Woodin and President Roosevelt and on May 24 he became executive assistant to Woodin. Dorfman $(1969,706)$ attributes Sprague's appointment partly to his well known "flexibility and moderation." The Roosevelt administration had added an valuable ornament. 
A presentation by Sprague - who was described as "Financial Executive Assistant to the Secretary of the Treasury" - to a meeting of the Federal Reserve Board with the Federal Open Market Committee on July 21,1933 , shows how remote Sprague was from seeing the crisis as one calling for lender-of-last resort actions or an expansionary monetary policy. Instead, Sprague was at the meeting to inform the Board that the Treasury was going to be issuing more debt; and to ask the Federal Reserve to enlist the help of "insurance companies, mutual savings banks, and banks in the interior of the United States" in floating the bonds. ${ }^{14}$ After Sprague left the meeting, this proposal, to judge by the minutes, was not discussed. The Committee, however, did reaffirm its bond-buying program, a decision endorsed by the Federal Reserve Board.

Sprague was not at the Treasury for long. On November, 16 1933, he resigned to protest Roosevelt's decision to devalue the dollar (New York Times, Nov 22, 1933; p. 2). Sprague was convinced that this policy would have disastrous consequences.

Sprague was not a lone voice, but his opinion undoubtedly carried a good deal of weight. Assistant Treasury Secretary Dean Acheson had

\footnotetext{
${ }^{14}$ Minutes of a meeting of the Federal Reserve Board with the Federal Open Market Committee Washington D.C., Friday, July 21, 1933; available at the Fraser Federal Reserve Archive, http://fraser.stlouisfed.org/
} 
resigned on November 15, probably for similar reasons, to be replaced by Henry Morgenthau Jr, but Acheson left quietly. On the 24th Alfred E. Smith, Roosevelt's political rival in the Democratic Party, attacked Roosevelt's gold policy. On December 28 a resolution criticizing the gold policy was released by the executive committee of the Economic National Committee on Monetary Policies that that was signed by E.W. Kemmerer, Wesley C. Mitchell, and 13 other eminent economists including Sprague. And on December 31 John Maynard Keynes was quoted as saying that the administration's policy was "more like a gold standard on booze" than an ideally managed currency (New York Times, January 2, 1934, p. 30). On the weightiness of Sprague's opinion, see the analysis by Arthur Krock in the New York Times (November 22, 1933, p. 2).

Meltzer $(2003,444)$ says that Sprague held "traditional views" about the gold standard which they undoubtedly were.${ }^{15}$ However, that does not mean that they were simply drawn from the conventional wisdom. They were consistent with his reading of U.S. financial history. Sprague saw the suspension of specie payments by the banks in previous financial crises as disastrous events. For example, the most serious phase of the Crisis of 1893 in Sprague's view was inaugurated by the suspension of specie

${ }^{15}$ Although Sprague did favor additional government spending on construction (Meltzer 2003, 444n.60) 
payments and the subsequent development of a "currency premium" (effectively a devaluation of the dollar) In August 1893 (Sprague 1910, 199203). The suspension, Sprague thought, could have been avoided had the New York banks shown sufficient leadership. In this case, Sprague was criticizing the New York banks for showing a lack of social responsibility much as Bagehot had criticized the Bank of England for failing to recognize its responsibilities.

What was the consequence of the suspension in 1893? In Sprague's $(1910,200)$ words "the suspension was a potent factor accentuating the depression in trade which characterized the month of August [1893]." For evidence, he turned to monthly earnings of the railroads (Sprague 1910, 201). In March through June 1893, railroad earnings were higher than they had been one year earlier. In July through December, they were lower than they had been a year earlier. The difference in July was - 4.85 percent, but in August, after the suspension, the difference was -13.29 percent. The difference in the difference makes Sprague's case. Thus, Sprague's opposition to Roosevelt's devaluation of the dollar was consistent with the lessons he drew in the History of Crises. ${ }^{16}$

\footnotetext{
${ }^{16}$ Friedman and Schwartz (1963, 163-68 and passim), in contrast argued that the suspensions served a therapeutic effect: protecting the banks and providing time for the panic to wear off. A paper by James, McAndrews, and Weiman (2013), however, confirms the negative effects of suspensions on economic activity, holding other factors constant.
} 
Despite Sprague's expertise and weighty reputation, the acting secretary of the Treasury, Henry Morgenthau Jr. does not appear to have been greatly troubled by Sprague's departure. Morgenthau was quoted in the New York Times (November 22, 1933, p. 1) as concluding, "I think the sun will rise tomorrow and the next day, and that the birds will sing." Shortly after resigning his Treasury position, Sprague published, as I noted above, Recovery and Common Sense (1934). Here he reiterated his view that trying to spur recovery by manipulating the value of the dollar was a major mistake.

\section{Prophetic Voices}

Sprague, America's greatest money doctor, misdiagnosed the Great Contraction. Were there others who got it right? The answer is yes, but very few.

One might have thought that there would be many references in the academic literature to Bagehot and Lombard Street, as academics pointed to the right way to meet a panic. A search of the economic and business journals on JSTOR, however, is revealing. Up to the year 1934, there were 25 articles - I did not look at book reviews and other short pieces - that 
mentioned Bagehot's Lombard Street. Only two authors, however, Lloyd Mints (1930) and Sprague (1909a, 1922) discussed the doctrine that the central bank should be the lender of last resort in financial crises. It may seem surprising that there were so many references to Lombard Street, and so few to the idea of a Lender of Last Resort. However, there is a great deal in Lombard Street besides the discussion of the lender of last resort. Lombard Street contains observations worth citing on bank reserves, the growth of credit, the differences between the American and British banking systems, and so on. One author cited one of Bagehot's trenchant aphorisms: "The abstract thinking of the world is never to be expected from persons in high places."

A search of the press for stories describing the current situation as a banking panic was also revealing. A search of the New York Times for the period January 1, 1930 to December 31, 1934 for articles in which the word "panic" occurred in the title and "bank" occurred in the title or text uncovered 78 articles. They referred, however, mostly to the stock market or to problems abroad. None identified a contemporaneous banking panic in the United States. A search of the Wall Street Journal for the same period produced similar results. There were nine articles in which the word "panic" occurred in the title and the word "bank" in the title or text. Most of 
these articles referred to the stock market crash or to events abroad. None suggested that there was a banking panic underway in the United States.

None of these articles was written by an economist, although one article did report on Irving Fisher's new book about the stock market crash. Perhaps the most interesting article was by the French novelist and man of letters André Maurois (1932). Maurois first compared a financial panic to a panic that breaks out in a theater when a lunatic shouts "fire." He then turned to a second metaphor. Soldiers may be stoical about familiar dangers, but may panic when confronted with a new weapon, as, Maurois claims, they did in World War I when first confronted with gas attacks. At first, the Depression was like a pre-war panic, and businesspersons were prepared to meet it stoically; they had been through this sort of thing before. Then a new and unknown danger emerged.
"In this new crisis currencies themselves suddenly gave way, like soft wax. Formerly when the currency of a nation fell there was a known limit to its drop. That was the "gold point." But now currencies famous for their stability passed the gold point, abandoned all gold value, ceased to be fixed points on which one could rely."

How could the panic be ended? Maurois thought that one thing that might help would be if "the governments of the great powers took some concerted action which would strike the imagination of the whole world." The moratorium on German reparation payments promoted by the Hoover 
administration was the right type of step, he thought, but too limited to have the desired effect. Maurois seems to have understood what many of the professional money doctors missed, there was a panic going on that needed to be addressed, although Maurois like Sprague focused on the dangers of currency fluctuations rather than bank failures.

\section{Conclusions}

Most financial historians now believe that the Great Depression in the United States could have been avoided, or at least greatly ameliorated, if the Federal Reserve had acted aggressively to stem the tide of bank failures that was engulfing the United States in the early 1930s. This view has been reinforced by the work of many scholars, for example by Friedman and Schwartz (1963), Allan H. Meltzer (2003), Ben Bernanke (1983) who identified a non-monetary channel connecting the banking panic with the industrial collapse, and by many recent studies.

Friedman and Schwartz argued that the correct medicine for the banking crisis was well known. Walter Bagehot had instructed policymakers about how to deal with banking panics in Lombard Street (1873). Knowing the right medicine, however, is not sufficient. One must also have the right diagnosis. In the Great Contraction, neither the Federal Reserve nor most 
of the outside experts recognized that a panic requiring a lender-of-last resort response was underway.

The Federal Reserve's failure has been attributed to many of the problems that can afflict a large government bureaucracy: internal conflicts, subservience to special interests, inertia, and so on. However, we still must ask why so many academic experts on money and banking who were not connected with the Federal Reserve also failed to sound the alarm.

In the case of O.M.W. Sprague, at the time the foremost American expert on financial crises, two factors appear to have been at work. First, the banking panics of the early 1930s did not exhibit the symptoms typical of the panics that Sprague had described in detail in his classic History of Financial Crises under the National Banking System (1910). The 1929-33 panic was not centered in the New York money market, there was no sudden failure "of a great firm which everybody trusted" to use Bagehot's phrase, the gold reserves of the Federal Reserve were not being depleted at an alarming rate, and short-term interest rates especially the call-loan rate were not advancing to very high levels. At least as far as these symptoms were concerned, the economy was suffering from a malady that was very different from earlier panics. 
The lack of an interest rate signal may well have been the most important. If a patient is suffering from pneumonia, a doctor expects to find a fever. If an economy is suffering from a banking panic, Sprague expected to see high interest rates. True, other symptoms of a panic were present, such as a high rate of bank closures and the symptoms that Friedman and Schwartz taught us to look for, a decline in the stock of money caused by a decline in the money multiplier, but they were not the signals for which Sprague was looking.

Sprague, moreover, was convinced that once a severe depression had taken hold, an expansionary monetary policy could do little to help. Monetary expansion would lower interest rates, but only by a very small amount. The demand for money was highly elastic. Production in turn was insensitive to interest rate changes because interest was only a small part of the cost of doing business.

Sprague, however, did worry a great deal about Roosevelt's decision to devalue the dollar. Sprague believed that this policy had severely damaged confidence in the financial system and the potential for recovery, a concern that was consistent with his belief that restriction of payments had done enormous harm during previous financial crises. To protest 
Roosevelt's policy Sprague resigned his position as special advisor to the U.S. Treasury.

With Sprague, we have the story of only one individual, albeit one who was extremely influential. Further research is needed to prove that Sprague's views were typical of weighty opinion. My tentative conclusion is that they were, and this was a major reason why intense actions by the Federal Reserve to reverse the crisis was lacking.

Today most monetary historians would see Sprague's failure to recognize that a banking panic calling for the Federal Reserve to act as lender of last resort, his opposition to an expansionary monetary policy once the economic contraction was in full swing, and his unwavering support for the gold standard as serious errors. Lest we be too harsh in condemning him, and threaten the great money doctor with a posthumous suit for malpractice, we should remember that the crisis of 2008 was not anticipated and was not diagnosed until well after it started because it too looked different from earlier crises. Here is the way Ben Bernanke (2012) explained the problem.

"The financial crisis of 2007-09 was difficult to anticipate for two reasons: First, financial panics, being to a significant extent selffulfilling crises of confidence, are inherently difficult to foresee. Second, although the crisis bore some resemblance at a conceptual level to the panics known to Bagehot, it occurred in a rather different institutional context and was propagated and amplified by a number 
of vulnerabilities that had developed outside the traditional banking sector. Once identified, however, the panic could be addressed to a significant extent using classic tools, including backstop liquidity provision by central banks, both here and abroad." 


\section{References}

Bagehot, Walter. 1924 [1873]. Lombard Street: A Description of the Money Market. London: John Murray.

Barber, William J. 1996. Designs within Disorder: Franklin D. Roosevelt, the Economists, and the Shaping of American Economic Policy, 1933-1945. Cambridge; New York: Cambridge University Press.

Bernanke, Ben S. 1983. "Nonmonetary Effects of the Financial Crisis in the Propagation of the Great Depression." The American Economic Review 73 (3) (Jun.): pp. 257-276.

. 2012. "Some Reflections on the Crisis and the Policy

Response." Speech delivered at "rethinking finance," a conference sponsored by the Russell Sage foundation and the century foundation. April 13 ed. New York: Russell Sage foundation.

Bignon, Vincent, Marc Flandreau, and Stefano Ugolini. 2012. "Bagehot for Beginners: The Making of Lender-of-Last-Resort Operations in the Mid-nineteenth Century." Economic History Review, May 2012, v. 65, iss. 2, pp. 580-608.

Board of Governors of the Federal Reserve System. 1959. All-bank Statistics, United States, 1896-1955. Washington: Washington, D.C.: Board of Governors of the Federal Reserve System.

. 1976. Banking and Monetary Statistics: 1941-1970.

Washington, D.C.: Board of Governors of the Federal Reserve System.

Carlson, Mark. Kris James Mitchener, Gary Richardson. 2011. "Arresting Banking Panics: Federal Reserve Liquidity Provision and the Forgotten Panic of 1929." Journal of Political Economy, Vol. 119, No. 5 (October), pp. 889-924.

Cole, Arthur H. Robert L. Masson, and John H. Williams. 1954. "O. M. W. Sprague 1873-1953." The American Economic Review, Vol. 44, No. 1 (Mar.), pp. 131-132. 
Dorfman, Joseph. 1969. The Economic Mind in American Civilization. Volume 5. New York: Augustus M. Kelley.

Friedman, Milton, and Friedman, Rose D. 1980. Free to Choose: a Personal Statement. 1st ed. New York: Harcourt Brace Jovanovich.

Friedman, Milton, and Anna J. Schwartz. 1963. A Monetary History of the United States, 1867-1960. National bureau of economic research. Studies in business cycles. Vol. 12. Princeton: Princeton University Press.

. 1970. Monetary Statistics of the United States: Estimates, Sources, Methods. New York: National Bureau of Economic Research. . 1986. "The Failure of the Bank of United States: A Reappraisal: A Reply". Explorations in Economic History 23 (2) (04): 199-204.

James, John A., James McAndrews, David F. Weiman. 2013. "Wall Street and Main Street: the Macroeconomic Consequences of New York Bank Suspensions, 1866-1914." Cliometrica, Volume 7, Issue 2. (May): 99130.

Lucia, Joseph L. 1985. "The Failure of the Bank of United States: A Reappraisal. Explorations in Economic History 22 (4) (10): 402-16.

McFerrin, John Berry. 1969. Caldwell and Company; A Southern Financial Empire. Nashville, Tenn.: Vanderbilt University Press.

Maurois, André. "1932 Panic: Its Cause and Its Cure." New York Times (1923-Current file); June 5, p. SM1.

Meltzer, Allan H. 2003, 2009. A History of the Federal Reserve. Vol. 1. Chicago: University of Chicago Press.

Mitchener, Kris James, and Gary Richardson. 2013. "Shadowy Banks and Financial Contagion during the Great Depression: A Retrospective on Friedman and Schwartz." The American Economic Review 103, no. 3: 73-78. 
Mints, Lloyd W. 1930. The Elasticity of Bank Notes. Journal of Political Economy, Vol. 38, No. 4 (Aug.), pp. 458-471.

Moen, Jon, and Ellis W. Tallman. 1992. "The Bank Panic of 1907: The Role of Trust Companies." The Journal of Economic History 52, no. 3: 611-30.

O'Brien, Anthony Patrick. 1992. The Failure of the Bank of United States: A Defense of Joseph Lucia: Note. Journal of Money, Credit and Banking 24 (3) (Aug.): pp. 374-384.

Richardson, Gary. 2007. "The Check Is in the Mail: Correspondent Clearing and the Collapse of the Banking System, 1930 to 1933." The Journal of Economic History, 67, no. 3: 643-71.

Richardson, Gary; and William Troost. 2009. "Monetary Intervention Mitigated Banking Panics during the Great Depression: QuasiExperimental Evidence from a Federal Reserve District Border, 19291933." Journal of Political Economy, December, v. 117, iss. 6, pp. 103173.

Rockoff, Hugh. 2018. "It Is Always the Shadow Banks: The Regulatory Status of the Banks That Failed and Ignited America's Greatest Financial Panics." In Coping with Financial Crises: Some Lessons from Economic History, edited by Hugh Rockoff and Isao Suto, 77-106. Studies in Economic History. New York: Springer Nature, Springer. . 2021. "Oh, How the Mighty Have Fallen: The Bank Failures and Near Failures That Started America's Greatest Financial Panics." The Journal of Economic History 81, no. 2: 331-58.

Rodgers, Mary Tone, and James E. Payne. 2014. "How the Bank of France Changed U.S. Equity Expectations and Ended the Panic of 1907." Journal of Economic History 74 (2): 420-48.

Sprague, Oliver Mitchell Wentworth. 1897. The English Woolen Industry in the Seventeenth and Eighteenth Centuries. Ph. D dissertation, Harvard.

. 1909a. "Central Banks." American Economic Association Quarterly, 3rd Series, Vol. 10, No. 1, Papers and Discussions of the 
Twenty-First Annual Meeting. December 28-31, 1908 (Apr.), pp. 359369.

. 1909b. "The Proposal for a Central Bank in the United States: a Critical View." The Quarterly Journal of Economics, Vol. 23, No. 3 (May), pp. 363-415

. 1910. History of Crises under the National Banking System. Washington: Govt. Print. Off.

. 1915. "The Crisis of 1914 in the United States." The American Economic Review 5 (3) (Sep.): pp. 499-533.

. 1922. "The Efficiency of Credit." Annals of the American Academy of Political and Social Science, Vol. 99, The Federal Reserve System-Its Purpose and Work (Jan.), pp. 218-221.

. 1930. "Lectures Delivered by Professor Oliver Mitchell Wentworth Sprague in a Course on Bank Management at the Harvard Graduate School of Business Administration." Harvard University Library.

. 1931. "Major and Minor Trade Fluctuations." Journal of the Royal Statistical Society, Vol. 94, No. 4, pp. 540-563

1934. Recovery and Common Sense. Boston, New York, Houghton Mifflin Co.

. 1938. "The Recovery Problem in the United States." The American Economic Review 28, no. 1: 1-7.

Sprague, O. M. W. and W. Randolph Burgess. 1929. "Money and Credit and their Effect on Business." In Recent Economic Changes in the United States. 2 volumes. Eds.: Committee on Recent Economic Changes of the President's Conference on Unemployment. New York: McGraw-Hill for the NBER, pp. 661-712.

Temin, Peter. 1976. Did Monetary Forces Cause the Great Depression? New York: Norton. 
Trescott, Paul B. 1992. "The Failure of the Bank of United States, 1930, a Rejoinder to Anthony Patrick O'Brien." Journal of Money, Credit and Banking 24 (3) (Aug.): 385-399.

U.S. Bureau of the Census. 1975. Historical Statistics of the United States, Colonial Times to 1970, Bicentennial Edition. Washington, D.C.

White, Eugene N. 2016. "How to Prevent a Banking Panic: the Barings Crisis of 1890." Paper presented at the Annual Meeting of the Economic History Association, September 16-18, 2016. https://eh.net/eha/wp-content/uploads/2016/08/White.pdf.

Wicker, Elmus. 1980. A Reconsideration of the Causes of the Banking Panic of 1930. The Journal of Economic History 40 (3) (Sep.): 571-83. 1996. The Banking Panics of the Great Depression. Cambridge: Cambridge University Press.

Withers, Hartley. 1909. The Meaning of Money. New York: E. P. Dutton \& company. 


\section{Table 1. Bank Balance Sheets, Selected Items, 1928-1934}

\section{All Commercial Banks}

\begin{tabular}{|c|c|c|c|c|c|c|c|c|c|c|c|}
\hline & $\begin{array}{l}\text { Total } \\
\text { Assets }\end{array}$ & $\begin{array}{l}\text { Currency } \\
\text { and Coin }\end{array}$ & $\begin{array}{l}\text { Change in } \\
\text { currency } \\
\text { and coin }\end{array}$ & $\begin{array}{l}\text { Total } \\
\text { Investmen } \\
\text { ts }\end{array}$ & $\begin{array}{l}\text { Total } \\
\text { Loans }\end{array}$ & $\begin{array}{l}\text { Total } \\
\text { Cash } \\
\text { Assets }\end{array}$ & $\begin{array}{l}\text { Total } \\
\text { Deposits }\end{array}$ & $\begin{array}{l}\text { Other } \\
\text { Dema } \\
\text { nd } \\
\text { Deposi } \\
\text { ts }\end{array}$ & Capital & $\begin{array}{l}\text { Surplus } \\
\text { and } \\
\text { Capital } \\
\text { Accounts }\end{array}$ & $\begin{array}{l}\text { change } \\
\text { in total } \\
\text { currency } \\
\text { and coin }\end{array}$ \\
\hline & $\begin{array}{l}\text { Million } \\
\text { \$s }\end{array}$ & $\begin{array}{l}\text { Million } \\
\text { \$s }\end{array}$ & $\%$ & Million \$s & $\begin{array}{l}\text { Million } \\
\text { \$s }\end{array}$ & $\begin{array}{l}\text { Million } \\
\text { \$s }\end{array}$ & $\begin{array}{l}\text { Million } \\
\text { \$s }\end{array}$ & $\begin{array}{l}\text { Million } \\
\text { \$s }\end{array}$ & $\begin{array}{l}\text { Million } \\
\text { \$s }\end{array}$ & $\begin{array}{l}\text { Million } \\
\text { \$s }\end{array}$ & $\%$ \\
\hline 1928 & 71,121 & 797 & & 18,146 & 39,346 & 9,454 & 58,138 & 24,864 & 3,610 & 5,344 & \\
\hline 1929 & 72,315 & 770 & -3.45 & 17,306 & 41,944 & 9,222 & 58,269 & 25,169 & 3,383 & 5,867 & -2.48 \\
\hline 1930 & 74,290 & 831 & 7.62 & 18,090 & 40,990 & 11,201 & 60,365 & 25,658 & 3,997 & 6,375 & 19.44 \\
\hline 1931 & 70,070 & 851 & 2.38 & 19,973 & 35,416 & 10,405 & 57,187 & 22,573 & 3,749 & 6,123 & -7.37 \\
\hline 1932 & 57,295 & 767 & -10.39 & 18,406 & 28,071 & 7,407 & 45,569 & 17,114 & 3,358 & 5,167 & -33.99 \\
\hline 1933 & 51,359 & 641 & -17.95 & 18,125 & 22,337 & 7,793 & 41,684 & 16,022 & 2,943 & 4,445 & 5.08 \\
\hline 1934 & 55,915 & 691 & 7.51 & 21,262 & 21,309 & 10,158 & 46,480 & 17,798 & 3,510 & 4,355 & 26.50 \\
\hline
\end{tabular}

\section{New York State National Banks}

\begin{tabular}{|c|c|c|c|c|c|c|c|c|c|c|c|}
\hline 1928 & 6,780 & 40 & & 1,627 & 3,374 & 1,322 & 5,223 & 2,995 & 334 & 544 & \\
\hline 1929 & 5,996 & 37 & -7.91 & 1,287 & 3,201 & 1,041 & 4,521 & 2,708 & 355 & 554 & -23.91 \\
\hline 1930 & 7,462 & 43 & 15.05 & 1,580 & 3,576 & 1,757 & 5,827 & 3,569 & 436 & 698 & 52.40 \\
\hline 1931 & 6,851 & 43 & -0.60 & 1,788 & 3,185 & 1,348 & 5,236 & 3,130 & 429 & 636 & -26.53 \\
\hline 1932 & 5,000 & 37 & -13.79 & 1,688 & 2,097 & 785 & 3,742 & 2,242 & 379 & 466 & -54.03 \\
\hline 1933 & 4,691 & 29 & -24.52 & 1,730 & 1,728 & 844 & 3,662 & 2,212 & 369 & 334 & 7.26 \\
\hline 1934 & 4,819 & 47 & 48.83 & 2,018 & 1,527 & 993 & 3,973 & 2,224 & 384 & 290 & 16.25 \\
\hline
\end{tabular}

Sources. All Commercial Banks: Board of Governors of the Federal Reserve System (1959, 30-33). New York State National Banks: Board of Governors of the Federal Reserve System $(1959,738-41)$. 
Table 2. The Balance Sheet of the Federal Reserve, Selected Items, 1928-1934

\begin{tabular}{|l|c|c|c|c|c|c|c|c|}
\hline & & 1928 & 1029 & 1930 & 1931 & 1932 & 1933 & 1934 \\
\hline Total Assets & \$s & 5,352 & 5,458 & 5,201 & 5,672 & 6,115 & 7,041 & 8,442 \\
\hline Gold & \$s & 2,506 & 2,784 & 2,906 & 2,933 & 3,110 & 3,524 & 5,124 \\
\hline Change in gold & $\%$ & & 10.5 & 4.3 & 0.93 & 5.86 & 12.5 & 37.43 \\
\hline $\begin{array}{l}\text { Total bills } \\
\text { discounted }\end{array}$ & \$s & 1,056 & 632 & 251 & 638 & 235 & 98 & 7 \\
\hline $\begin{array}{l}\text { Total U.S. } \\
\text { Securities }\end{array}$ & $\$$ s & 228 & 511 & 729 & 817 & 1,855 & 2,437 & 2,430 \\
\hline $\begin{array}{l}\text { Total Deposits } \\
\text { Notes in } \\
\text { Circulation }\end{array}$ & \$s & 2,440 & 2,414 & 2,414 & 2,517 & 2,561 & 2,865 & 4,405 \\
\hline $\begin{array}{l}\text { Reserve Ratio } \\
\text { Capital }\end{array}$ & 1,838 & 1,910 & 1,664 & 2,624 & 2,739 & 3,080 & 3,221 \\
\hline $\begin{array}{l}\text { Surplus and } \\
\text { Capital Accounts }\end{array}$ & \$s & 254 & 277 & 275 & 259 & 279 & 300 & 184 \\
\hline
\end{tabular}

Source and Notes: Board of Governors of the Federal Reserve System (1976, pp. 331332). Dollar figures are in millions. 
Figures 1-6 Short-term Interest Rates in U.S. Financial Crises

Sources: NBER Macro History Database: Series, m13001 (call money) and m13002 (commercial paper), m13003 (Ninety Day Time Money Rates), and m13018a (Excess of New York Commercial Paper Rates Over London Discount Rates On Three Month Bank Bills).

Figure 1

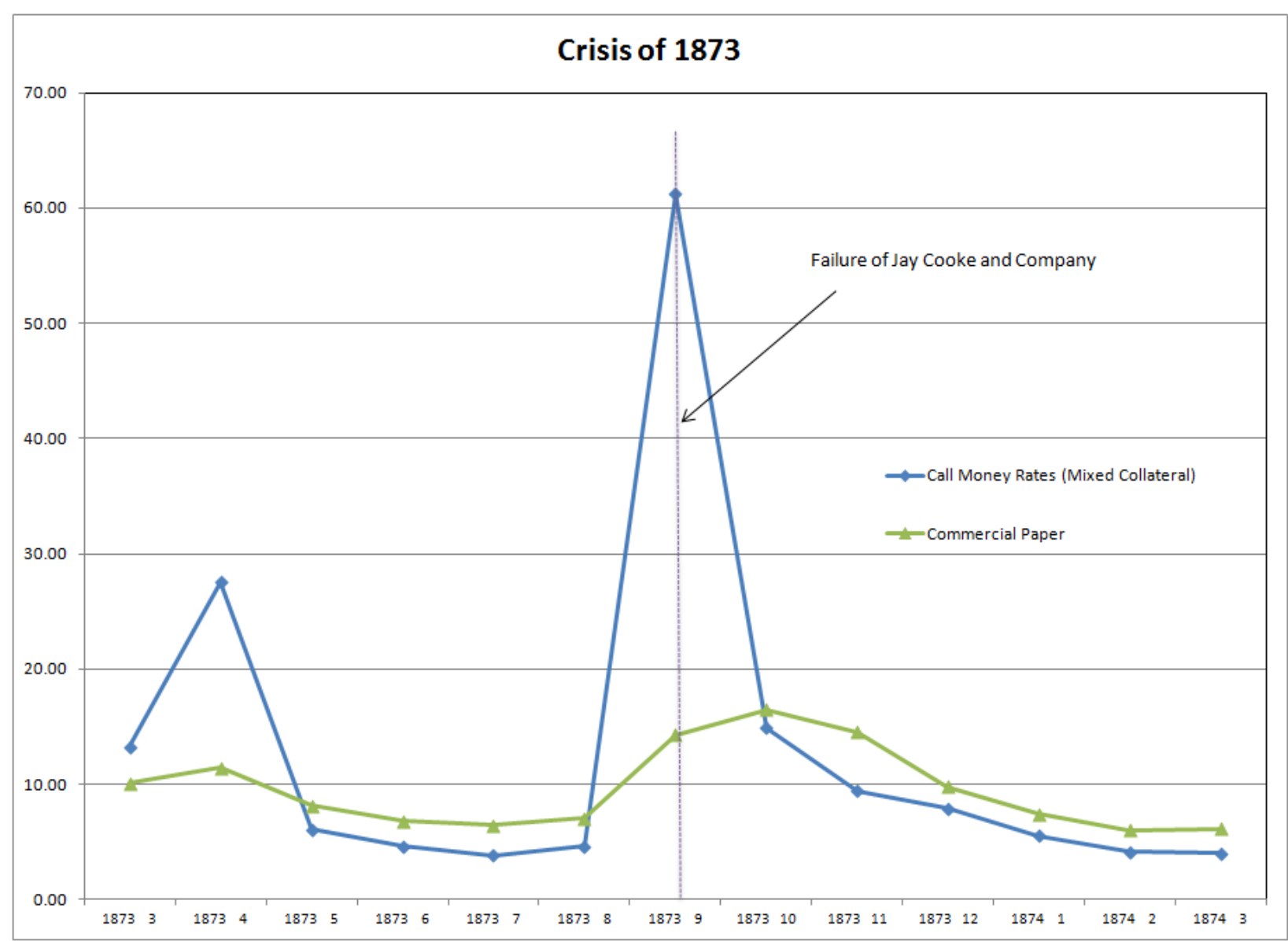


Figure 2

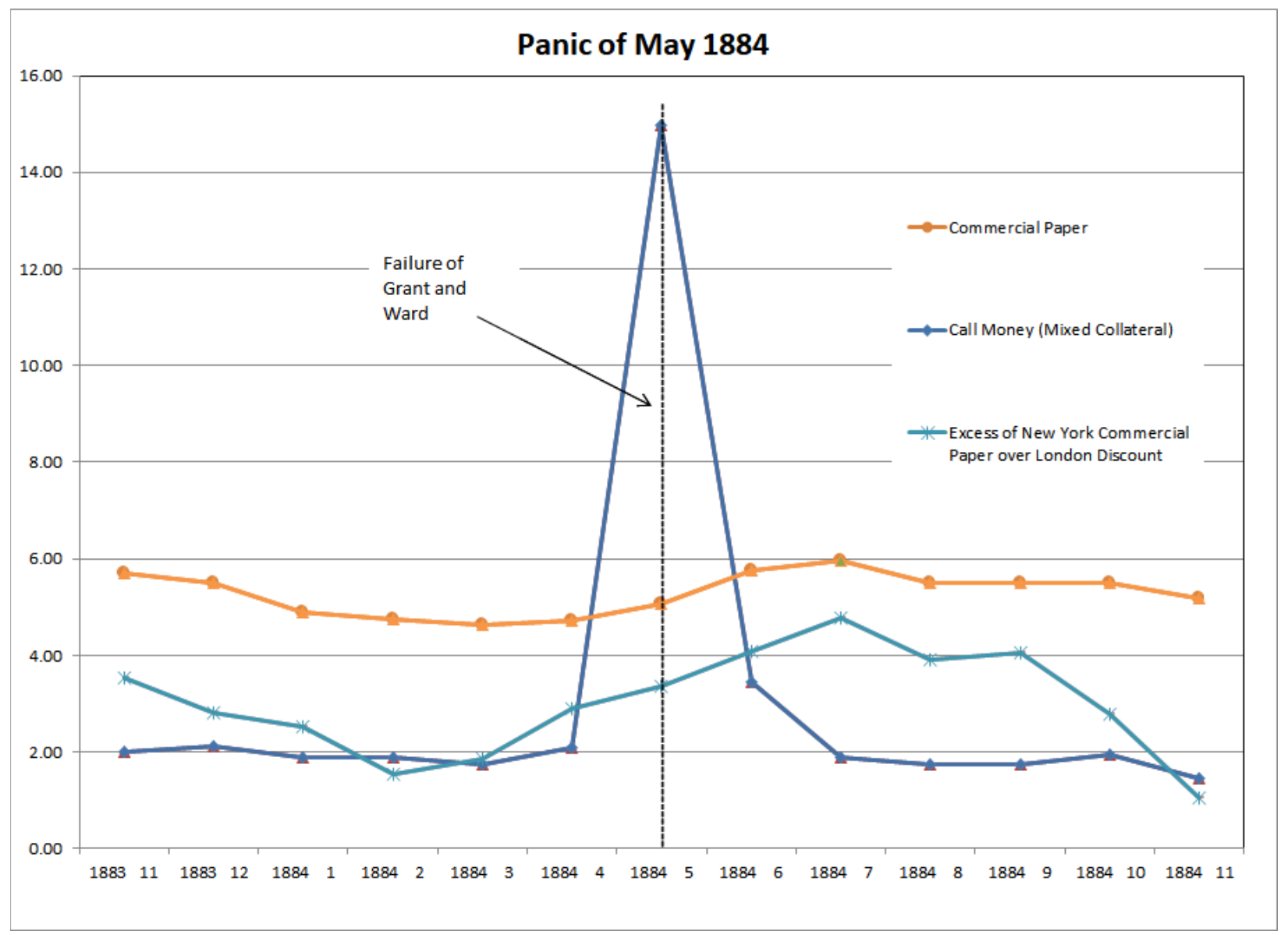




\section{Figure 3}

\section{Financial Stringency of 1890}

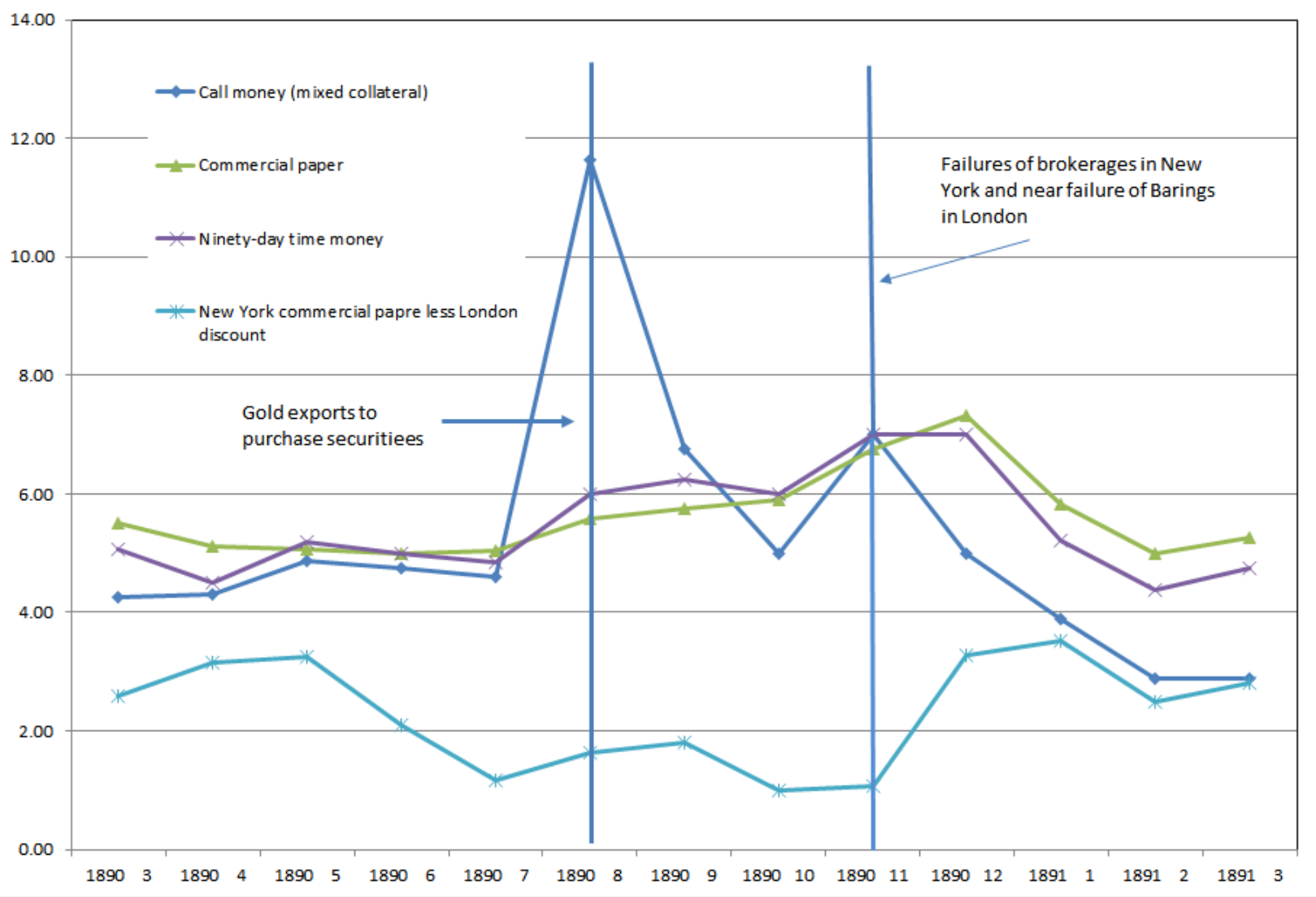


Figure 4

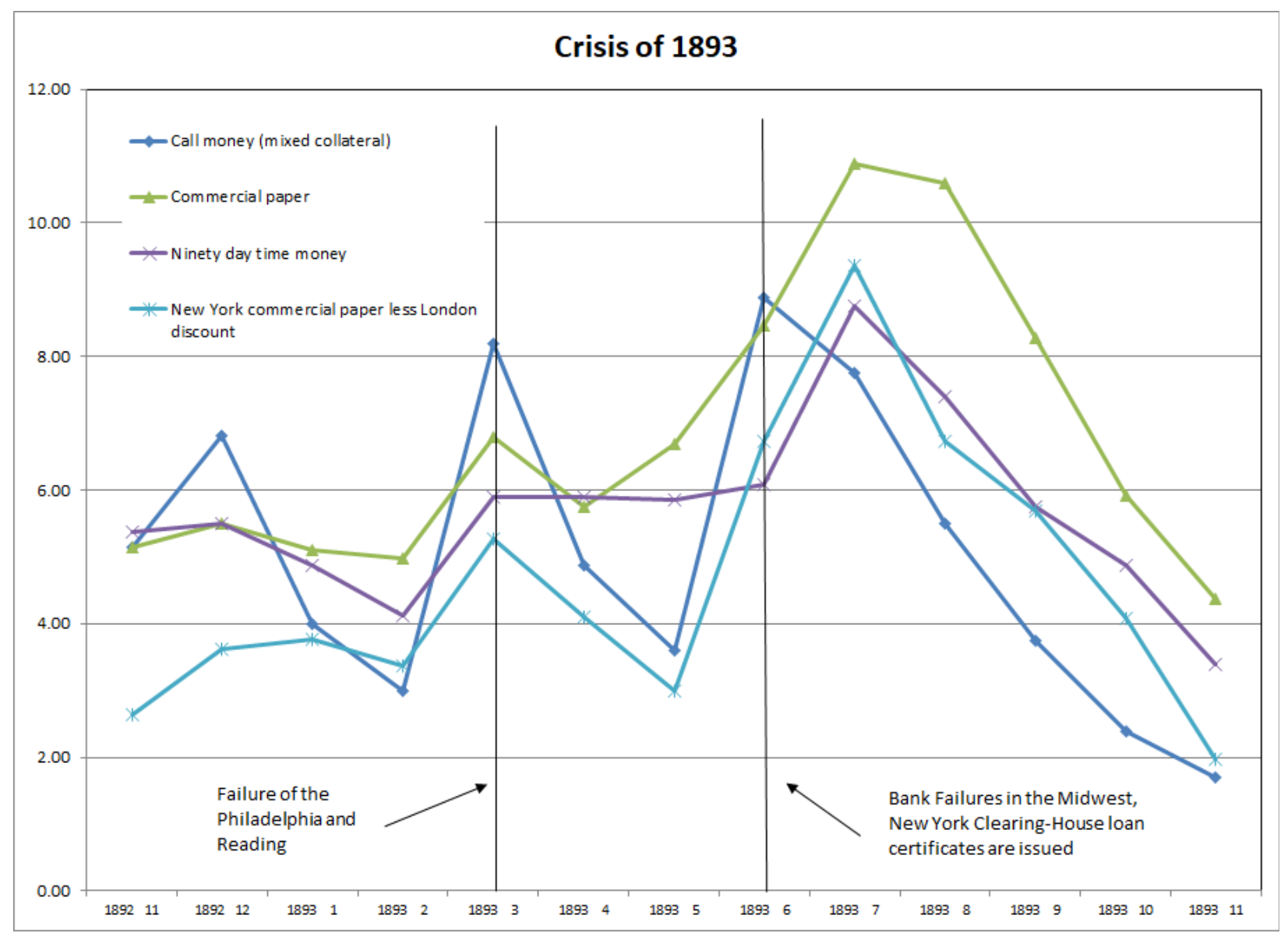


Figure 5

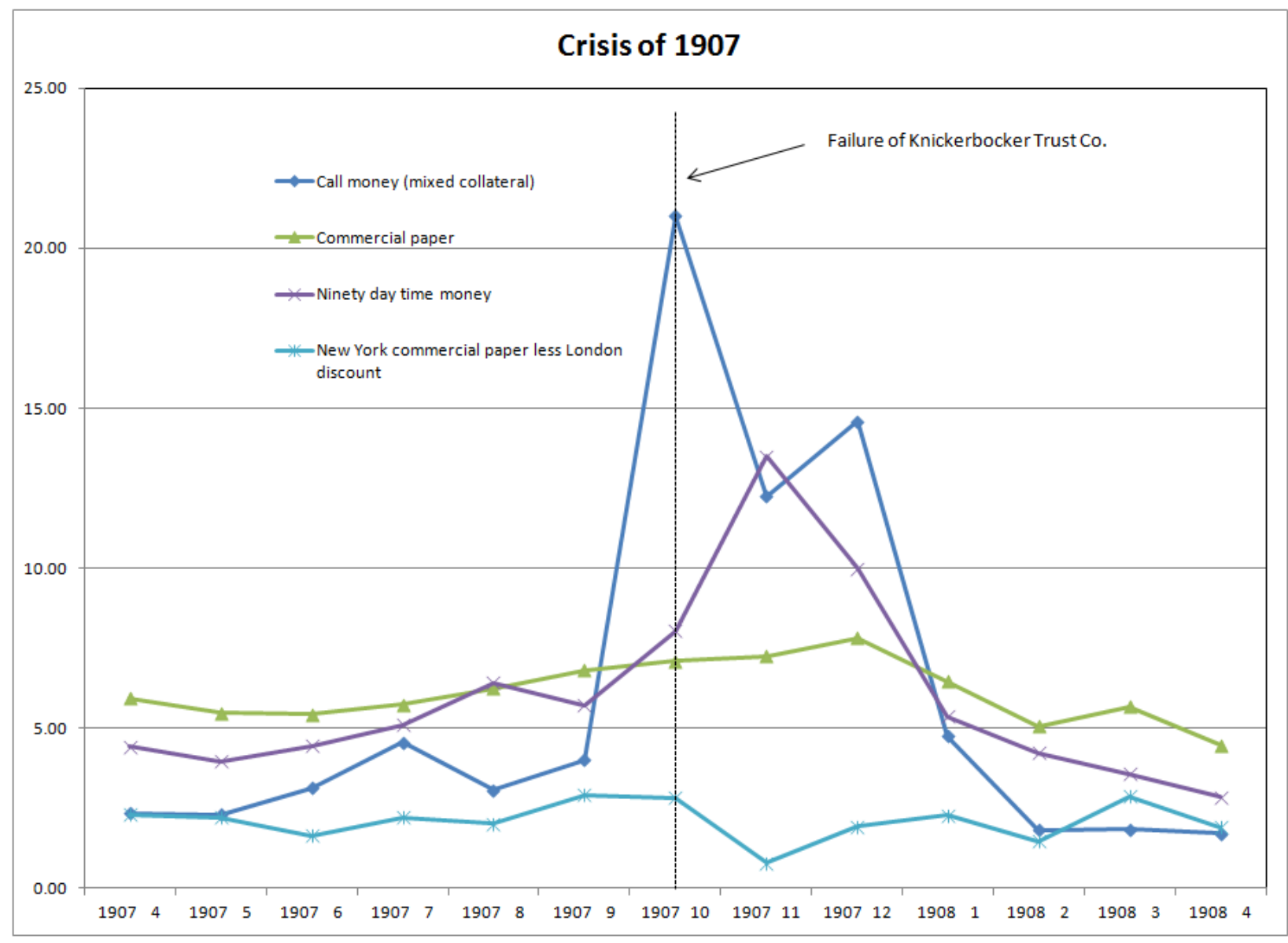


Figure 6

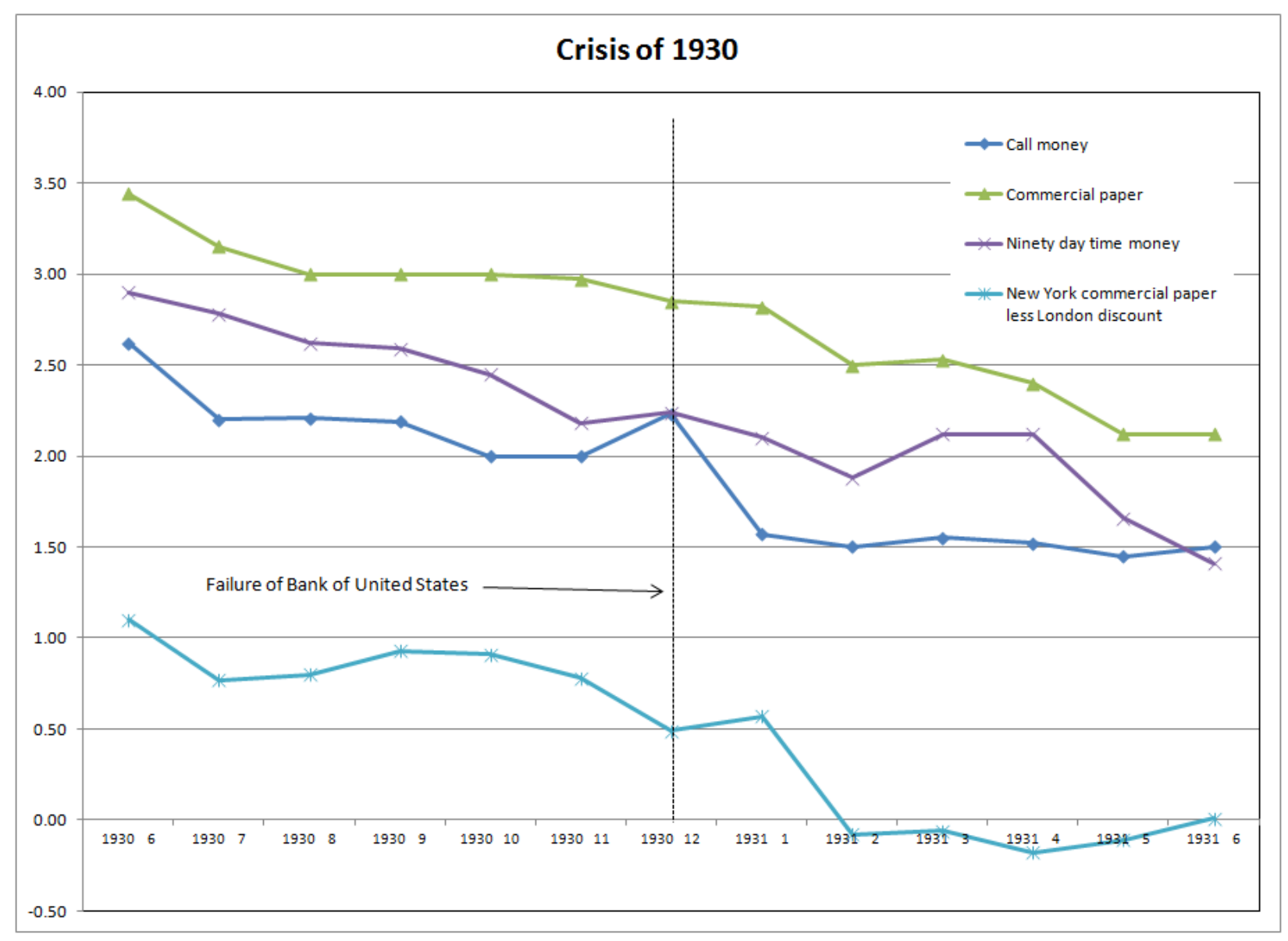


Figure 7

Source: U.S. Bureau of the Census (1975, series X-588 and X-741).

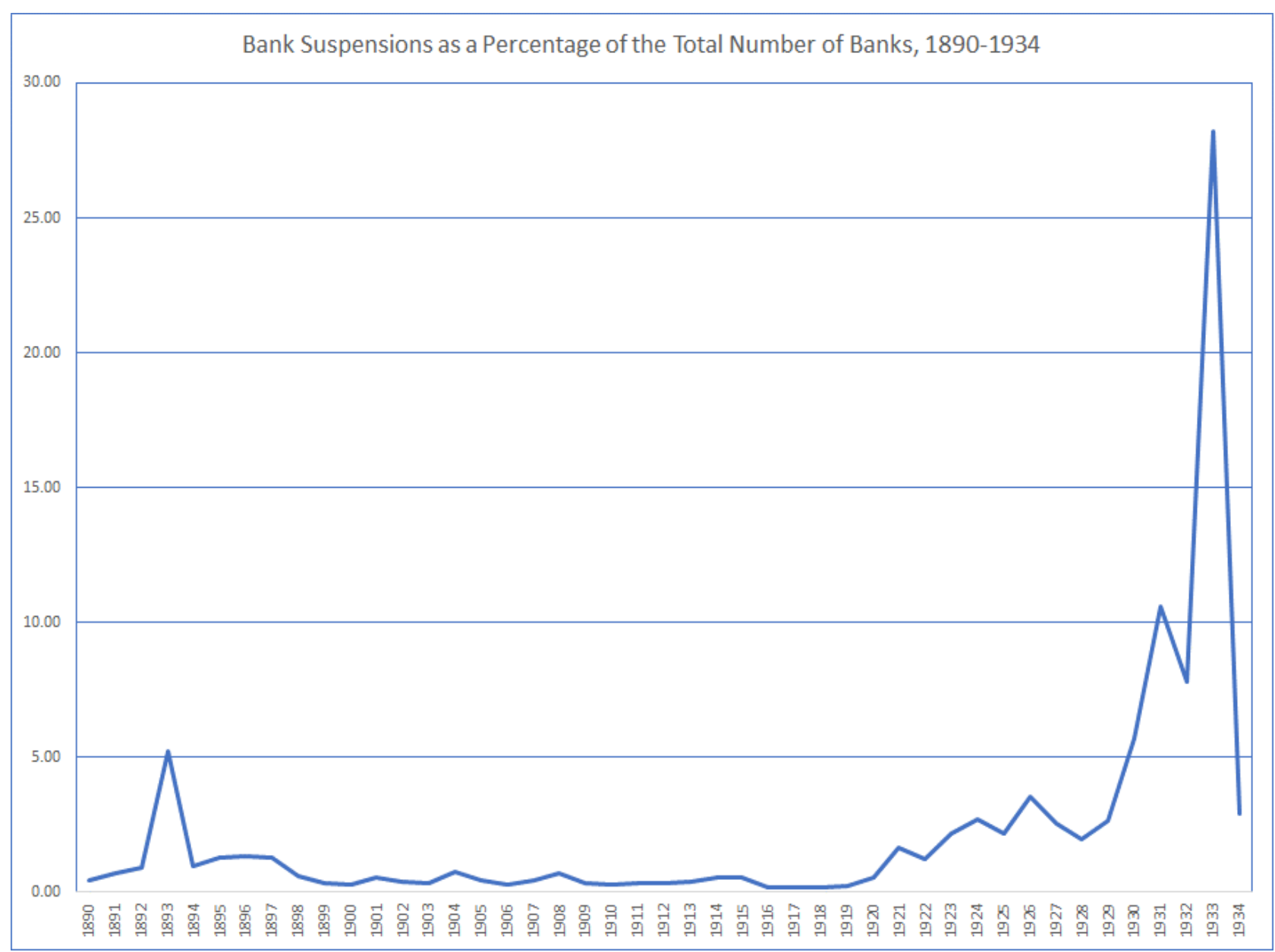


Figure 8

The deposit-reserve ratio and the deposit-currency ratio in the Great Contraction, 1929-1933.

Source: Friedman and Schwartz (1963, Table B3, pp. 799-804).

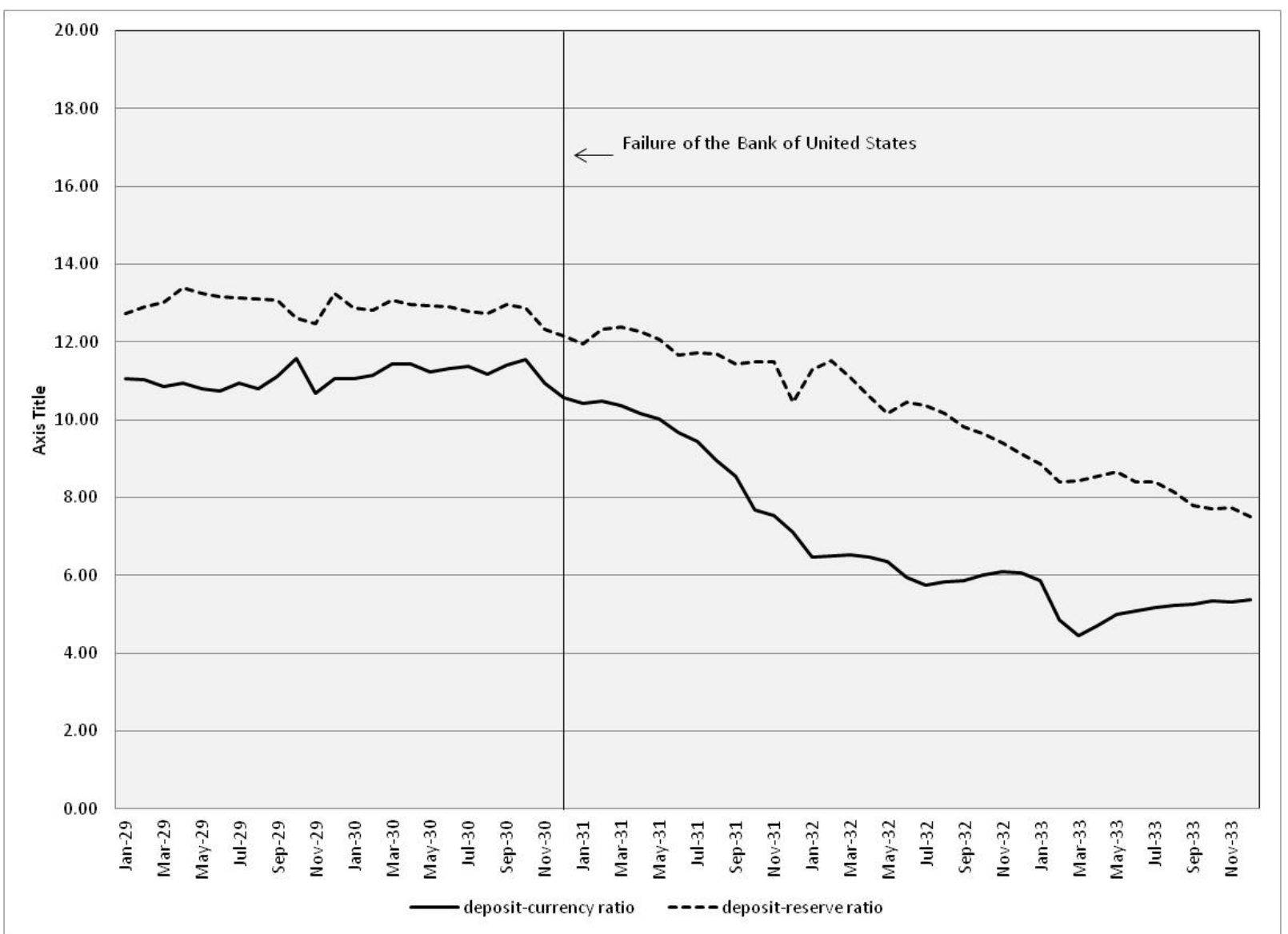




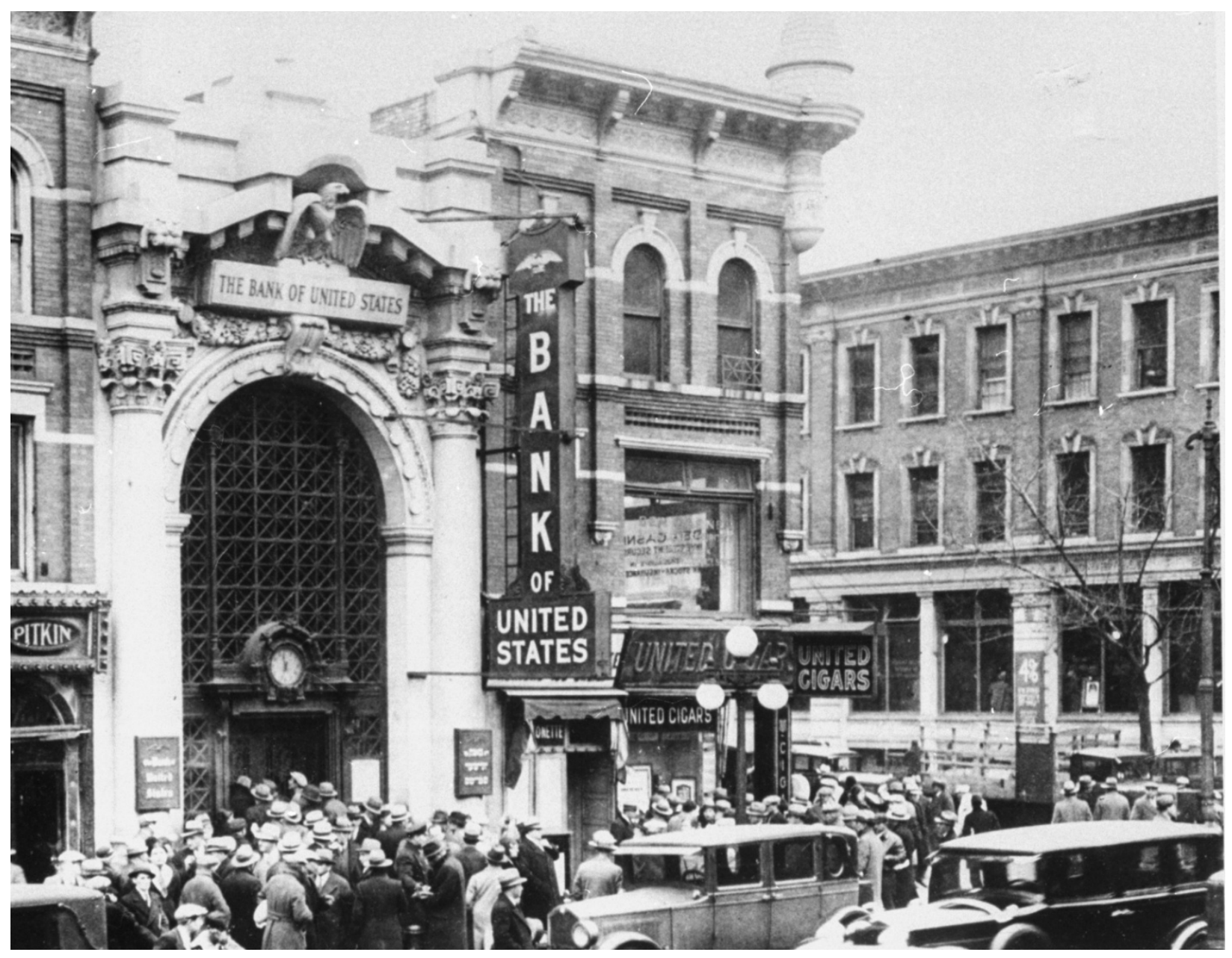

The run on the Bank of United States in December 1930.

But was the bank "systemically important”? 